\title{
The Impact of the Market Cycle on the Value Relevance of Book Values and Earnings in the Banking Industry: An Evidence from Poland
}

\author{
P.M. Bolibok, \\ The John Paul II \\ Catholic University of Lublin, \\ Poland \\ https://orcid.org/0000-0002-5649-181X
}

\begin{abstract}
The paper aims at the empirical investigation of the impact of the market cycle on the value relevance of book values and earnings in the banking industry. Unlike most prior studies, the paper directly examines the influence of cyclical fluctuations in investors' sentiments on the informativeness of these key accounting variables. Moreover, the study enhances the literature on the value relevance of banks' financial reporting by providing an empirical evidence from the emerging capital market of Poland. The examined sample covers all domestically-based commercial banks listed on the Warsaw Stock Exchange over the period 1997-2016. The empirical evidence based on the analyses of parametric and non-parametric correlation and regression indicates a significant impact of the market cycle on the value relevance of book values which markedly increases (decreases) in the periods of bull (bear) market. In contrast, the informativeness of earnings seems to be driven primarily by factors other than investors' sentiments. The results of the research indicate that the course of the market cycle is partially driving the fluctuations of the value relevance of book values of equity and net earnings in the Polish banking industry. There is a need for further investigation of the impact of market cycles on the value relevance of accounting data, not only in the context of the banking sector.
\end{abstract}

Keywords: Market cycle; value relevance; accounting information; banks, book values; earnings

For citation: Bolibok P.M. The Impact of the Market Cycle on the Value Relevance of Book Values and Earnings in the Banking Industry: An Evidence from Poland. Finansy: teoriya i praktika = Finance: Theory and Practice. 2018;22(2):6-25. DOI: 10.26794/2587-5671-201822-2-6-25 


\title{
Влияние рыночного цикла на значимость балансовой стоимости и доходов в банковской индустрии Польши
}

\author{
П.М.Болибок, \\ Люблинский католический университет имени Иоанна Павла II, \\ Люблин, Польша \\ https://orcid.org/0000-0002-5649-181X
}

\begin{abstract}
АННОТАЦИЯ
Цель статьи - эмпирическое исследование влияния рыночного цикла на актуальную стоимость балансовых активов и доходов в банковской отрасли. В отличие от большинства предыдущих исследований, в статье непосредственно рассматривается влияние циклических колебаний настроений инвесторов на информативность этих ключевых переменных учета. Кроме того, исследование дополняет литературу, касающуюся проблематики стоимостной оценки финансовой отчетности банков, предоставляя эмпирические данные с формирующегося рынка капитала в Польше. Исследуемая выборка охватывает все отечественные коммерческие банки, котирующиеся на Варшавской фондовой бирже в период 1997-2016 гг. Эмпирические данные, основанные на анализе параметрической и непараметрической корреляции и регрессии, свидетельствуют о значительном влиянии рыночного цикла на стоимостную оценку балансовых значений, которая заметно возрастает (уменьшается) в периоды «бычьего» («медвежьего») состояния рынка ценных бумаг. В отличие от этого, информативность доходов, как представляется, определяется, главным образом, факторами, отличными от настроений инвесторов. Результаты исследования показывают, что течение рыночного цикла частично приводит к колебаниям актуальной балансовой стоимости собственного капитала и чистой прибыли в польской банковской отрасли. Однако необходимо продолжить изучение влияния рыночных циклов на ценностную оценку данных бухгалтерского учета, причем не только по отношению к банковскому сектору.

Ключевые слова: рыночный цикл; оценка стоимости; бухгалтерская информация; банки; балансовая стоимость; прибыль
\end{abstract}

Для цитирования: Болибок П.М. Влияние рыночного цикла на значимость балансовой стоимости и доходов в банковской индустрии Польши. Финансы: теория и практика. 2018;22(2):6-25. DOI: 10.26794/2587-5671-2018-22-2-6-25

\section{INTRODUCTION}

The informational content of financial reports undoubtedly plays a key role in the valuation of listed companies and subsequent decisions of equity investors [1]. Since a seminal study by Ball and Brown [2] the international literature exploring the relationship between reported accounting data and market values has become abundant. Despite a large body of literature regarding the issue of value relevance of accounting data, most studies exclude banks from the examined samples.

The specificity of banking operations and their recognition in accounting ledgers allows, however, to expect a relatively high degree of coherence between the reported view of banks' financial position with its perception by the equity investors, in particular due to valuation of the vast majority of banks' assets and liabilities at amortized cost or at fair value estimates. A high share of financial assets and liabilities also makes banks less subject to conservative accounting with respect to their on-balance-sheet items which creates a favourable context for investigation of the value relevance of accounting data. Moreover, banks' stocks are usually among the most liquid securities in a given market, which gives a rationale for expecting an increased market efficiency in response to the available information. Additionally, a high degree of homogeneity in the banks' operations 
significantly reduces cross-sectional variation in factors that might affect estimates of regression models used for investigation of associations between accounting items and market values [3].

The association-based studies typically examine relatively long periods of time [49] during which the overall market sentiments may vary significantly. Given an increased volatility of stock prices in recent decades, an interesting research question is, therefore, whether the course of the market cycle affects the investors' perception of disclosed accounting information.

In the times of bull market, investors may easily become overoptimistic about companies' expected future performance, which is likely to drive the stock prices above their intrinsic values estimated on the basis of reported accounting information. In contrast, during the periods of adverse macroeconomic conditions and increased risk aversion the effects might be exactly opposite, as prevailing negative sentiments and emotional reactions of investors may bring stock prices significantly below the fundamental values.

This issue seems particularly worth examining in relation to the fundamental and most comprehensive measures of listed companies' overall financial position and performance, i.e. book values of equity and earnings. Book values are often viewed as proxies for company's abandonment or liquidation value [4], whereas an analysis of the quality and persistence of historical earnings allows to assess the company's past performance and thus to formulate or revise the expectations about the future cash flows $[5]^{1}$. Earnings conservatism and persistence, in turn, forecasts of future cash flows influence the expected future dividend paying capacity that ultimately determines the market value of company's shares [6]. Furthermore, the available international empirical evidence suggests that in the context of banking sector each of these variables seems highly value-relevant (see e.g., 7-9).

During the last decades stock markets all over the world experienced several strong and rapid shifts of investor sentiments. Therefore, an increased volatility of stock prices is likely to be only partially driven by the changes in the underlying fundamental factors, with the remainder largely attributable to the emotional reactions of the equity investors. A particularly deep negative

\footnotetext{
${ }^{1}$ The empirical evidence suggests that earnings persistence in the banking industry seems to be partially dependent on the relative size of book value of equity. According to AmorTapia, Bona-Sánchez, Pérez-Alemán, \& Tascón-Fendández [10] the level of Tier 1 capital is negatively related to earnings conservatism, since earnings increases become more persistent and earnings reversals following earnings declines tend to be higher as Tier 1 decreases.
}

impact on investors' sentiments in recent years was caused by the global financial crisis started in the U.S. subprime mortgage market. The crisis not only brought a serious and prolonged contraction of economic activity in both developed and emerging economies around the world but also significantly increased investors' risk aversion and changed their perception of the available value-relevant accounting information.

The banking sector is, in fact, the one where the crisis actually began and exerted the most explicit impact. Initially, banks in many countries suffered severe losses on their portfolios of financial assets exposed to the U.S. subprime mortgage market risks. Afterward, a spreading recession led to the deterioration of the quality of their loan portfolios, while increasing risk aversion constrained the opportunities for further growth. The results of these adverse conditions were subsequently recognized in banks' accounting ledgers, affecting both earnings, book values, and ultimately the market values.

A relatively conservative model of banking activity and a negligible exposure to the U.S. subprime market risks allowed the Polish banking industry to avoid the direct impact of the first stage of the global crisis. Additionally, high profitability and strong capital adequacy offered a decent protective cushion against adverse shocks from the global environment. Initially, the crisis caused a significant, however transitory, surge in risk aversion and a decrease of liquidity in the interbank money and FX markets. The major long-run impact of the crisis on the Polish banking sector resulted, in turn, from the economic downturn that damaged the creditworthiness of borrowers and deteriorated the quality of banks' loan portfolios [11].

Naturally, recognition of changes in the creditworthiness of borrowers in banks' accounting ledgers is not immediate, but affects the levels of impairment provisions and ultimately earnings and book values with a considerable lag. Moreover, during the periods of adverse macroeconomic conditions the volatility of earnings and the share of their transitory components significantly increase [12], which in addition to often erratic movements in stock prices weakens the association between banks' earnings and market values.

Given the above intuition, the paper aims at investigating the impact of the market cycle, and in particular the periods of economic downturns, on the value relevance of book values of equity and earnings reported by banks in the context of the Polish capital market. To author's knowledge, this issue has not been yet directly examined empirically, therefore the present study attempts to fill this apparent gap and enhance the existing value relevance literature regarding the banking industry in the emerging markets. 
The remainder of the paper is organized into six sections. The next section provides a review of the international literature on the value relevance of accounting information in the banking industry and the impact of market cycles on the relationship between banks' financial reporting and market value. Section 3 provides a brief overview of the Polish capital market. The details of methodological framework of the paper and data selection procedures are described in section 4. The fifth section presents the key empirical findings of the study. The paper is closed with discussion and conclusions, including some suggestions on the directions of future research.

\section{LITERATURE REVIEW}

\subsection{Value relevance of accounting variables in the banking industry}

The majority of empirical evidence on value relevance of accounting data in the banking sector regards fair value disclosures of debt and equity securities (see e.g., [13-18]), bank loans (see e.g., [16, 17, 19, 20]), and derivatives (see e.g., [14, 16, 17, 21, 22]).

The literature referring directly to the value relevance of banks' book values and earnings seems relatively modest. A pioneering study by Philips and Mayne [23] demonstrates a strong association between discounted banks' stock values and operating earnings per assets, and a weaker, but not negligible, relation with nonoperating earnings components (realized and unrealized security gains and losses).

The majority of early studies on the value relevance of the components of banks' earnings focused on impairment provisions. Although intuitively these items should be valued negatively by the equity investors, the results of several studies suggest an exactly opposite effect. According to Wahlen [24], impairment provisions consist of discretionary and non-discretionary components. The discretionary component is subject to bank managers' manipulation and dependent on their motivation, whereas the non-discretionary one is an outcome of objective events lying beyond management's control resulting mostly from exposure to the default risk. Bank managers might use the discretionary component to convey positive signals about the future cash flow prospects which, in turn, leads to its positive relationship with banks' market value. Although some studies provide evidence supporting the signaling hypothesis (e.g., [25]), the results of others are undermining it [26-28].

A study by Ryan, Tucker, and Zarowin [29] investigating the value relevance of banks' trading operations demonstrates that stock returns in the banking industry are more positively associated with the trading revenue (operating) component than with the principal cash flow (non-operating) component of those operations. Implying, therefore, a hybrid nature of such operations that is not fully captured by a standard cash flow statement framework. In turn, Hodder, Hopkins, and Wahlen [30] argue that incremental volatility in full-fair-value income (a constructed measure of income that includes unrealized fair-value gains or losses on financial instruments) beyond the volatility in net earnings and comprehensive income, negatively moderates the relation between abnormal earnings and banks' share prices, and positively affects the expected return implicit in bank share prices. Full-fair-value volatility seems to reflect, therefore, elements of risk that are not captured by the variance in net earnings or comprehensive income, and as such appears to be more closely related to capitalmarket pricing of banks' risk.

The value relevance of banks earnings with respect to banks' risk is also investigated in the studies by Cheng and Ariff [31], Cheng and Annuar [32], and Soh, Cheng, and Annuar [33]. They demonstrate that market value response to changes in earnings is determined by bank risk factors, resulting in particular from the credit and interest rate risk. Interestingly, Cheng and Ariff [31] report a better fit of regression between abnormal returns on bank stocks and earnings change factor than in the case of studies on the earnings-to-price relation in non-bank industries.

Kohlbeck and Warfield [3] find a significant positive association between the levels of bank unrecorded intangible assets and abnormal earnings in residual income model framework. They also report that this association becomes stronger for banks with higher proportions of deposit intangibles. Moreover, the pricing multiples for abnormal earnings increase from lower to higher levels of unrecorded intangible assets.

A study by Abuzayed, Molyneux, and Al-Fayoumi [34] addresses the problem of the information content of earnings and their components. Their results suggest that both earnings and their components are value relevant and can explain the gap between market and book values of banks. Additionally, the components of net earnings seem more value relevant than their aggregate numbers.

Another attempt to investigate the value relevance of banks' earnings components was made by Siam and Rashid [35]. The results of their analyses are, however, ambiguous. On the one hand, they report a significant relationship between the market price of equity and earnings components deflated by market capitalization. By contrast, the same variables deflated by the book value of equity reveal no statistical significance and a very low explanatory power. In turn, Al-Horani [36] examines the differences in the value relevance of earnings com- 
ponents from traditional and non-traditional banking activities, finding that for small banks annual abnormal returns have a positive relationship with changes in the non-interest component of earnings and a negative relationship with changes in their traditional interest component. In contrast, annual abnormal returns for large banks have a negative relationship with changes in the non-interest component of earnings.

Dimitropoulos, Asteriou, and Koumanakos [37] argue that earnings levels and changes are able to explain more of the cross-sectional variation of bank stock returns than the level and change of cash flows, which supports the claim that earnings have incremental information beyond that of cash flows. In the presence of transitory earnings, however, cash flows become more value relevant than earnings. According to Tjhoa and Hermawan [38], however, the relative value relevance of earnings and cash flows in the banking sector might depend on contextual factors specific for the particular market setting.

Some further evidence supporting the value relevance of banks' financial reporting can also be found in the context of the emerging capital market of Poland. Using the approach based on the modified version of the Ohlson [39] residual income valuation model Bolibok [40] demonstrates that book values of equity and perpetuities of residual incomes calculated on the basis of net earnings are highly-value relevant. Moreover, the market value of listed banks in Poland appears to be most strongly related to book values of equity followed by net earnings. In contrast, banks' cash flows do not provide any significant incremental explanatory power beyond that conveyed by book values of equity and net earnings [9], which seems consistent with the results obtained in the developed capital markets (see e.g., [41]).

Several recent studies examining the banking industry addressed the issue of the impact of different accounting standards on the value relevance of book values of equity and earnings. Their results are, however, ambiguous. Escaffre and Sefsaf [7] examined this issue in the U.S. and some selected European markets (Belgium, Netherlands, Luxembourg, France, Spain and Great Britain). Their results suggest that book values of equity and earnings are more value-relevant in the European markets reporting under IFRS than in the American market under U.S. GAAP. Additionally, the study by Agostino, Drago, and Silipo [42] conducted on the sample of listed banks from 15 EU countries demonstrates that implementation of IFRS enhanced the information content of both book values and earnings for more transparent banks, but the less transparent ones did not experience any significant increase in the value relevance of book value.
The results of an extensive investigation by Anandarajan et al [8] examining banking institutions from 38 countries over the period 1993-2004 indicate that at the macro-level the value relevance of earnings and book values of equity is affected by the disclosure requirements of a country's standards boards (the greater disclosure of financial information required, the higher value relevance). They also found that the value relevance increases when the local environment is more focused on the private sector and the legal environment is more friendly to shareholders. Contrary to the findings of Escaffre and Sefsaf [7] they claim, however, that British American banks are more value relevant as they operate in regulatory regimes associated with greater levels of transparency.

The impact of IFRS adoption on the value relevance of banks' book values of equity and earnings in Poland was investigated by Bolibok [43, 44]. His results suggest that mandatory adoption of IFRS did not improve the value relevance of these accounting variables, which seems consistent with the evidence for the non-financial sector in that setting $[45,46]$.

Even though the aforementioned studies conducted in the banking industry typically examine multi-year periods they usually neglect a potential impact of the market cycle on the observed value relevance of accounting variables. In turn, the studies aimed at the exploration of this impact, rarely offer explicit evidence for the banking industry.

\subsection{The impact of the market cycle on the value relevance of accounting variables}

Changing macroeconomic conditions undoubtedly affect the equity investors' perception of business opportunities and risk. During expansions, as the overall financial position of enterprises improves, investors might become overoptimistic in their expectations of the companies' future performance and the persistence of reported earnings. They are also more likely to underestimate the riskiness of future cash flows. These tendencies could, in turn, result in positively-biased estimates of stocks' intrinsic values made on the basis of reported accounting data. In contrast, the periods of economic downturns elevate the riskiness of business activity and worsen the overall performance of enterprises, increasing the number of them reporting losses. Moreover, a transitory nature of recessions tends to increase the share of non-recurring components of earnings, which in turn makes them less useful for financial forecasts and valuation purposes. It is not surprising then, that a considerable body of literature demonstrates a negative impact of economic downturns on the value relevance of reported earnings (see e.g., [47-49]). 
Davis-Friday and Gordon [50] provide an evidence of a negative impact of the 1994 Mexican currency crisis on the value relevance of accounting data. They argue that during the crisis an increased frequency of losses contributed to declines in both valuation coefficient and incremental explanatory power of earnings. On the other hand, however, they did not find any significant change in the valuation coefficient on book values of equity, even though their incremental explanatory power increased.

Several studies investigated the impact of Asian financial crisis of 1997 on the value relevance of accounting data. The findings of Graham, King, and Bailes [51] indicate that the recession following the depreciation of Thai currency deteriorated the total value relevance of book values and earnings in Thailand. In the post-crisis period, however, the incremental explanatory power of book values over earnings increased, while that of earnings over book values decreased, mostly due to the high volatility of foreign exchange gains and losses. In turn, a study by Ho, Liu, and Sohn [52] demonstrated that in South Korea the crisis caused a significant drop in the value relevance of earnings which, however, was not compensated by the increasing value relevance of book values. A comparative study by Eng, Nabar, and Chng [53] investigated the effects of the Asian crisis on the markets of Hong Kong, Malaysia, Singapore, and Thailand revealing a positive association between earnings and future excess stock returns in the periods before and after the crisis, which suggests that investors might have undervalued these accounting items. In contrast, during the crisis, this association became negative indicating an actual overvaluation of earnings.

Johnson [54] argues that the value relevance of earnings reported by listed companies is sensitive to the course of the business cycle. Her research demonstrates explicitly that during the periods of expansion the association between earnings and stock returns tends to increase while in times of contraction it becomes markedly lower.

Jenkins, Kane, and Velury [55] argue that the information content of accounting numbers varies across the business cycle since it reflects both the impact of general economic conditions and the effects of the company's business activities. In times of contraction companies' growth prospects captured by current earnings may be perceived by the equity investors as more uncertain. Contrary to Johnson [54], however, they demonstrate that, after controlling for firms' growth, the responsiveness of stock prices to variation in earnings actually tends to increase during recessions.

Bepari [56] provides an evidence of structural breaks in the association of book values and earnings with firms' market value in the aftermath of the global financial cri- sis in Australia. He argues that the relevance of earnings increases and that of book values decreases during the crisis compared to the non-crisis period. Additionally, the explanatory power of earnings during the crisis seems to be greater than that of the book values.

The findings of an extensive study by Persakis and Iatridis [57], covering over 137 thousand firm-year observations of non-financial enterprises from 18 developed countries suggest that during the global financial crisis an overall earnings quality declined. They argue that adverse economic conditions might incline managers to recognize potential positive events more frequently than they normally would, which increases the share of accruals and lowers earnings quality.

Kane et al. [12] examined the impact of economic downturns on the value relevance of earnings and book values of equity of non-financial enterprises in the U.S. market over the period 1970-2012. Their results indicate that recessions, due to their transitory nature, tend to limit the persistence of reported earnings, and thus deteriorate their value relevance. On the other hand, however, as recessions induce higher risk into business operations, they are likely to increase the value relevance of book values of equity.

Just as in the case of other areas of the market-based accounting research, the empirical evidence on the impact of market cycles on the value relevance of accounting variables in the banking sector is rather modest. Most related studies are focused primarily on the impact of economic downturns on the quality of banks' earnings and earnings management practices. In particular, Cohen, Cornett, Marcus, and Tehranian [58] demonstrate that banks using more aggressive earnings management prior to 2007 exhibited substantially higher stock market risk as measured by the incidence of extreme declines in stock prices. In turn, Ma and Song [59] argue that earnings management increases banks' contribution to systemic crash risk and systemic distress risk due to higher information opacity, stimulation of bad news hoarding and co-movement with macroeconomic conditions.

Using a large sample of U.S. banks Morris, Kang, and Jie [60] examine the changes in the value relevance of discretionary loan loss provisions in the period preceding and succeeding the recent global financial crisis. Their findings indicate that in the period of falling premanaged earnings (2006-2008) the market appeared to reward the attempts to measure reported earnings more conservatively. In contrast, when earnings started to rise again during 2009-2010, the market seemed to reward the efforts to smooth the reported earnings downwards. Additionally, it seems that during downturns investors tend to value conservatively calculated earnings of relatively poorly performing banks, but during expansions, 
Table 1

Summary statistics of the WSE Main List

\begin{tabular}{|c|c|c|c|c|c|c|c|}
\hline \multirow{2}{*}{ Characteristics } & \multicolumn{6}{|c|}{ Year } & \multirow[b]{2}{*}{2016} \\
\hline & 1991 & 1995 & 2000 & 2005 & 2010 & 2015 & \\
\hline \multicolumn{8}{|l|}{ Number of listed companies } \\
\hline - domestic & 9 & 65 & 225 & 248 & 400 & 433 & 434 \\
\hline - foreign & 0 & 0 & 0 & 7 & 27 & 54 & 53 \\
\hline - new listings & 9 & 21 & 13 & 35 & 34 & 30 & 19 \\
\hline - delistings & 0 & 0 & 9 & 10 & 13 & 13 & 19 \\
\hline \multicolumn{8}{|l|}{ Main index (WIG) } \\
\hline - value (points) & 919 & 7,586 & 17,848 & 35,601 & 47,490 & 46,467 & 51,754 \\
\hline - return (\%) & -8.09 & 1.50 & -1.30 & 33.66 & 18.77 & -9.62 & 11.38 \\
\hline $\begin{array}{l}\text { Number of investment accounts } \\
\text { (thousands) }\end{array}$ & 54 & 808 & 1236 & 853 & 1477 & 1417 & 1395 \\
\hline \multicolumn{8}{|l|}{$\begin{array}{l}\text { Market capitalization (in EUR } \\
\mathrm{mln} \text { ) }\end{array}$} \\
\hline - domestic & 110 & 3,567 & 33,788 & 79,901 & 137,032 & 121,883 & 126,046 \\
\hline - foreign & 0 & 0 & 0 & 30,177 & 64,100 & 133,509 & 126,379 \\
\hline Total turnover (in EUR mln) & 110 & 2,820 & 21,101 & 24,474 & 58,651 & 53,846 & 46,371 \\
\hline \multicolumn{8}{|l|}{ Selected market indicators } \\
\hline - Average P/E & 4.10 & 7.80 & 28.50 & 15.50 & 18.20 & 18.30 & 17.30 \\
\hline - Average P/BV & 0.47 & 1.47 & 1.98 & 2.06 & 1.16 & 1.05 & 0.82 \\
\hline - Dividend yield (\%) & 0.00 & 2.30 & 0.80 & 1.80 & 2.40 & 2.30 & 3.40 \\
\hline - Turnover velocity (\%) & 18.50 & 67.50 & 42.90 & 22.30 & 45.30 & 36.10 & 37.80 \\
\hline
\end{tabular}

Source: WSE, 2017.

they value smoothed earnings of banks performing better than their peers.

Apparently, the only prior study related to the impact of economic downturns on the value relevance of accounting data in the Polish banking industry is the one by Bolibok [61] who investigated the influence of the recent global financial crisis on the value relevance of financial leverage. His results indicate that perception of leverage by the equity investors has changed significantly since the beginning of the crisis. In the pre-crisis period, leverage appeared to have a positive, yet not significant, impact on banks' market value. After the crisis broke out, however, this impact has become significantly negative, which could reflect a structural change in investors' attitudes, resulting from increased uncertainty and risk aversion in that period.

Given the above, the impact of the market cycle on the value relevance of accounting variables in the banking sector seems to be largely unexplored. Moreover, apparently, no prior study has directly examined this 


\section{The market capitalization of the Warsaw Stock Exchange compared to selected European stock exchanges as of December 31 $1^{\text {st }}, 2016$}

\begin{tabular}{|l|c|}
\hline \multicolumn{1}{|c|}{ Stock exchange } & Value (in EUR bln) \\
\hline Warsaw Stock Exchange & 130.99 \\
\hline Bolsas y Mercados Españoles & 669.39 \\
\hline Bucharest Stock Exchange & 16.81 \\
\hline Budapest Stock Exchange & 21.27 \\
\hline Bulgarian Stock Exchange & 4.95 \\
\hline CEESEG - Prague & 22.19 \\
\hline CEESEG - Vienna & 95.20 \\
\hline Deutsche Börse & $1,630.41$ \\
\hline Euronext & $3,287.23$ \\
\hline Irish Stock Exchange & 113.85 \\
\hline London Stock Exchange & $5,371.32$ \\
\hline Moscow Exchange & 582,06 \\
\hline Oslo Børs & 219.48 \\
\hline SIX Swiss Exchange & $1,131.27$ \\
\hline
\end{tabular}

Source: Federation of European Stock Exchanges, 2018; London Stock Exchange, 2018; World Federation of Exchanges, 2018.

issue in the context of the emerging capital market of Poland. Therefore, the present study attempts to fill this gap and thus contribute to the existing literature on the value relevance of banks' financial reporting.

\section{THE DEVELOPMENT OF THE POLISH CAPITAL MARKET}

The history of the capital market in Poland dates back to 1817 when the Warsaw Mercantile Exchange was established. This event places Poland among the countries with the longest securities trading traditions in Europe. Paradoxically, the break in Warsaw Exchange's activity caused by the World War II and the subsequent introduction of the communist regime, has created an unprecedented opportunity of establishing a modern capital market, taking advantage of the best solutions implemented elsewhere in Europe.

The transformation of Poland from a communist to a democratic state and the transition to a market economy that started in 1989, required many fundamental economic reforms. One of the essential issues to be addressed at that time was the need for privatization of enterprises, which demanded the development of a properly functioning capital market. In 1990, Poland and France signed a cooperation agreement to establish a securities exchange in Warsaw. The Foundation Act for the Warsaw Stock Exchange [WSE], as a treasury-owned joint stock company, was signed on April 12 ${ }^{\text {th }}, 1991$. Four days later the first trading session was held, with five listed companies.

During just over twenty-five years of its operations, the WSE has become one of the most dynamic capital markets in Europe, taking an unquestionable leadership in Central and Eastern Europe in terms of capitalization, trading volume and the number of new market entrants. Among the crucial factors that boosted the development of the stock exchange in Poland, the following two seem to be of special importance: the reform of the Polish pension system in 1999 that enabled establishment of open pension funds and Poland's accession to the European Union in 2004, which greatly enhanced the trading volume in subsequent years.

Table 1 presents some key statistical characteristics of the Main List of WSE for the selected years of its history.

Currently, the WSE places among the medium-sized European stock exchanges in terms of market capitalization of listed companies (Table 2).

At the end of 2016, the market capitalization of domestic companies listed on the WSE equity markets reached 130.99 billion euros, i.e. nearly 40 percent more than the value for the second-largest stock exchange 
of Central and Eastern Europe - CEESEG - Vienna. In comparison to other major markets in the region, the advantage of the WSE is even more pronounced. When compared to the leading stock exchanges in Europe, however, the market capitalization of the WSE remains only a small fraction of their levels.

In terms of IPOs, the WSE has been among the top European exchanges for a number of consecutive years. With 25 IPOs in 2016, the WSE placed third, behind the Nasdaq OMX Exchange (80) and London Stock Exchange (67), but ahead of Bolsas y Mercados Españoles (24), Euronext (23), and Borsa Italiana (14) ${ }^{2}$.

The Polish capital market, being still relatively young and dynamic, seems therefore particularly interesting for investigation of the impact of the market cycle on the value relevance of accounting data.

\section{RESEARCH DESIGN}

The results of prior studies on the value relevance of book values and earnings in the banking sector, along with the modest empirical evidence regarding the impact of business cycles on the value relevance of banks' accounting numbers and the apparent lack of related studies in the context of the Polish banking industry allow formulating the following research hypotheses:

Нуротнеsis 1. The value relevance of book values of equity and earnings of banks listed on the Warsaw Stock Exchange is influenced by the market cycle.

НүротнеSIs 2. The value relevance of earnings is relatively more unstable a sensitive to the course of the market cycle than the value relevance of book vues of equity.

HyPothesis 3. The periods of economic downturn and increased risk aversion tend to deteriorate the value relevance of book values of equity and earnings in the banking sector.

In order to test the above hypotheses, a multi-step research process has been employed. In the first stage, the market values of the examined banks have been linearly regressed on the book values of equity and net earnings in each year of the analyzed period using the following models:

$$
\begin{aligned}
& \text { Model 1: } \widetilde{p}_{t}=\alpha_{0}+\alpha_{1} B V P S_{t}+\varepsilon_{t} . \\
& \text { Model 2: } \widetilde{p}_{t}=\beta_{0}+\beta_{1} E P S_{t}+\zeta_{t} .
\end{aligned}
$$

where:

$p_{t}$ - closing price of a bank's share at the end of pe$\operatorname{riod} t$;

\footnotetext{
${ }^{2}$ Pricewaterhouse Coopers. IPO Watch Europe 2016. URL: https://www.pwc.co.uk/audit-assurance/assets/pdf/ipowatch-europe-annual-review-2016.pdf.
}

$\alpha_{0}, \beta_{0}$ - intercepts;

$\alpha_{1}, \beta_{1},-$ structural parameters;

$B V P S_{t}$-book value of equity per share at the end of period $t$,

$E P S_{t}-$ net income per share for the period $(t-1 ; t)$,

$\varepsilon_{\hat{t}}, \zeta_{t}$ - error terms.

Given the evidence in the prior international and domestic literature, increases in both BVPS and EPS should result in higher prices of banks' stocks, which allows expecting positive values of the estimates of parameters $\alpha_{1}$ and $\beta_{1}$. The error terms serve for capturing the influence of potential factors not included in the models. The above regressions have been run independently using the data from both separate and consolidated financial statements.

Next, the estimated yearly regression coefficients for book values and earnings have been compared with yearly returns of the broadest market index of the WSE main list, i.e. WIG, which allows investigating the hypothesized associations between the course of the business cycle and the value relevance of the examined accounting variables. The direction and relative strength of these associations have been assessed using both parametric and non-parametric correlation measures (the Pearson linear regression coefficient and the Spearman's rank correlation coefficient), and a linear regression analysis. Additionally, analogous analyses have been run between the WIG index yearly returns and the yearly coefficients of determination for each model.

The final stage of the research aims at capturing the impact of economic downturns on the value relevance of banks' book values of equity and earnings in the pooled sample of observations over the entire examined period. In order to achieve this goal, the following multiple regression model has been employed:

$$
\begin{gathered}
\text { Model 3: } \widetilde{p}_{t}=\gamma_{0}+\gamma_{D 0} D_{t}+\gamma_{1} B V P S_{t}+\gamma_{2} E P S_{t}+. \\
\gamma_{3}\left(D_{t} B V P S_{t}\right)+\gamma_{4}\left(D_{t} E P S_{t}\right)+\vartheta_{t}
\end{gathered}
$$

where:

$p_{t}-$ closing price of a bank's share at the end of period $t$

$$
\begin{aligned}
& \gamma_{0}-\text { intercept; } \\
& D_{t}-\text { dummy variable equal } 0 \text {, if } \mathrm{R}_{\mathrm{WIGt}} \geqslant 0 \text {, and } 1 \text { if }
\end{aligned}
$$
$\mathrm{R}_{\text {WIGt }}<0$,

$\mathrm{R}_{\mathrm{wIGt}}-$ WIG Index yearly return in the period $(t-1 ; t)$, $\gamma_{D O}, \gamma_{1}, \gamma_{2}, \gamma_{3}, \gamma_{4}-$ structural parameters;

$B V P S_{t}$ - book value per share at the end of period $t$; $E P S_{t}$ - net income per share for the period $(t-1 ; t)$, $\vartheta_{t}$ - error term.

Parameters $\gamma_{1}$ and $\gamma_{2}$ serve for capturing the sensitivity of banks' stock prices to changes in both book values of 


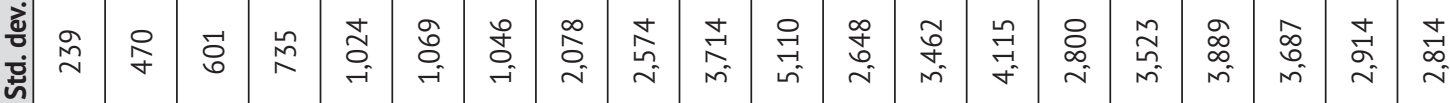

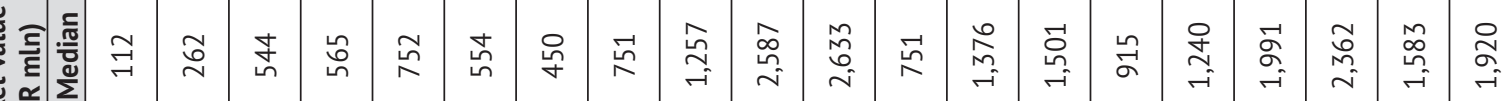

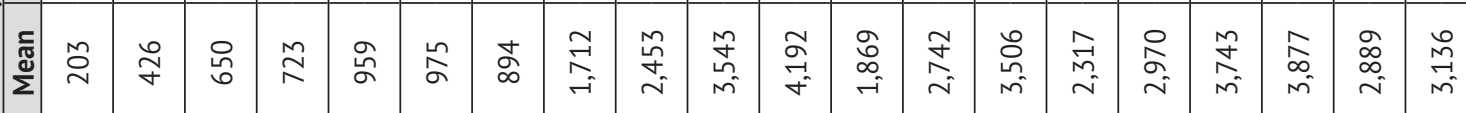

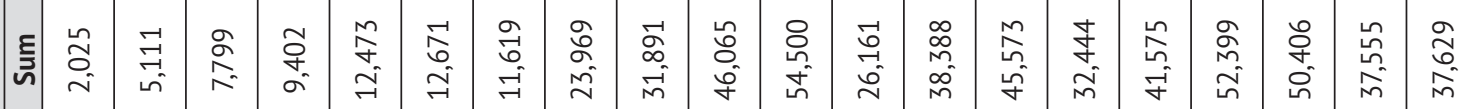

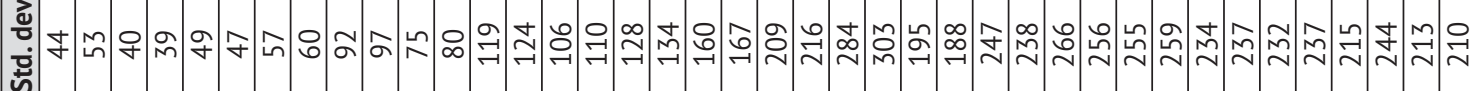

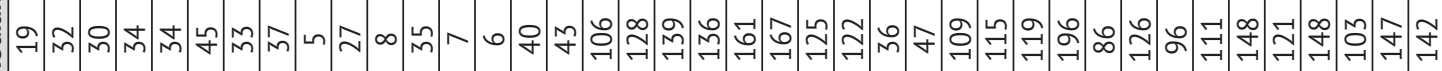

芩

究

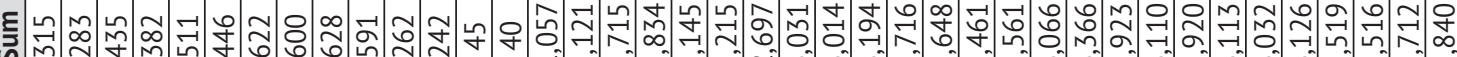

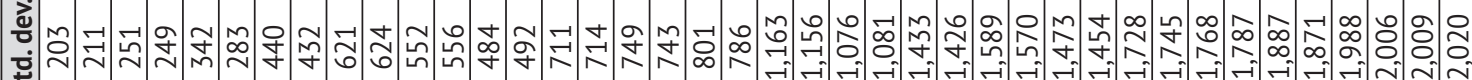

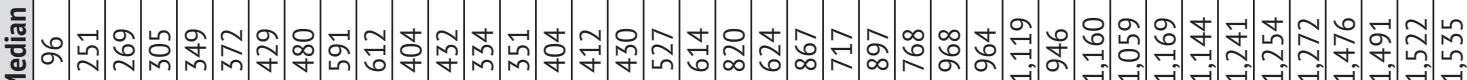
突

然 ๘ँ

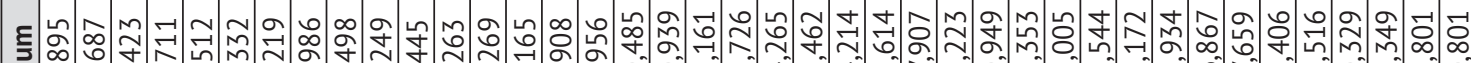

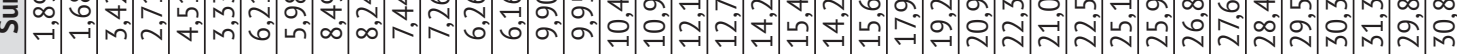

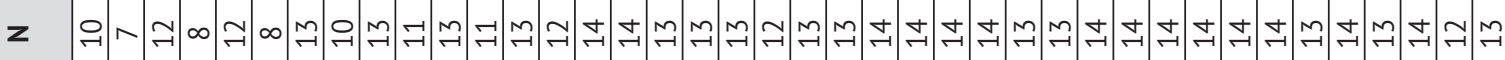

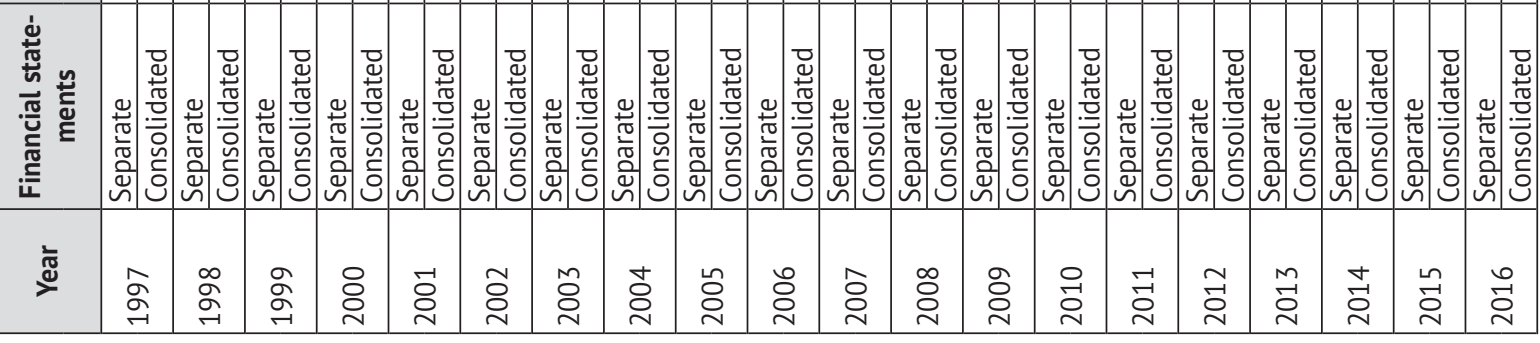


equity and net earnings per share, respectively, in the periods of a bull market. In turn, parameters $\gamma_{3}$ and $\gamma_{4}$ represent the average changes in the values of regression coefficients for BVPS and EPS, correspondingly, in the bear market conditions.

Given the hypothesized adverse impact of economic downturns on the value relevance of accounting information reported by banks, the estimates of parameters $\gamma_{3}$ and $\gamma_{4}$ are expected to be negative. Usually, in the periods of contractions, higher uncertainty, risk aversion and a stronger impact of investors' emotional reactions are likely to drag stock prices further away from their intrinsic values, rendering the accounting data less relevant. The results of several prior studies suggest, however, that in the times of increased economic instability and risk aversion, the value relevance of equity book values might increase, as it often serves as a proxy for company's liquidation value and systematic risk sensitivity [12]. In order to assess the statistical significance of changes in the regression parameters, the Chow test for a structural break has been employed [62].

The examined sample covers all domestically-based commercial banks listed on the Warsaw Stock Exchange over the period 1997-2016. Taking into account the mergers and acquisitions within the sector, the final sample comprised 19 banks. The data on annual financial statements have been collected from the Notoria Serwis SA database provided by Emerging Markets Information Service $^{3}$, while the data on historical stock prices have been extracted from the database of the Brokerage House of Bank Ochrony Środowiska SA (2018). The combined data on book values of equity, net earnings and stock prices yield the unbalanced pooled samples of 260 bankyear observations for the separate financial statements and 243 ones for the consolidated data.

The basic descriptive statistics of the year-end market capitalization, book values of equity and net earnings of the examined banks are summarized in Table 3. The joint market capitalization of the banks in the sample covered from nearly 18 to over $46 \%$ of the total capitalization of domestic companies listed on the WSE over the analyzed period.

\section{EMPIRICAL RESULTS}

The results of estimations of Models 1 and 2 for both separate and consolidated financial statements by year are presented in Table 4 .

As expected, the regression coefficients between separate book values oequity and banks' stock prices are

\footnotetext{
${ }^{3}$ Emerging Markets Information Service. URL: https:// www-1 emis-1 com-1qzu6libc0996.han.bg.up.lublin.pl/cgibin/comp_profiles.
}

positive and statistically significant at the level of $\mathrm{p}<$ 0.01 in each year of the analyzed period. The sensitivity of stock prices to changes in BVPS, however, varies significantly from 1.249 in 2015 and 2016 to 3.255 in 2006, with a mean of 1.849 and a median of 1.695 . The coefficient of determination for Model 1 ranges from 0.806 in 2011 to 0.991 in 1997, indicating that changes in BVPS are able to explain a vast majority of variance in banks' stock prices.

The estimates of regression parameters for Model 2 are also positive and generally statistically significant. Their $p$-values are not exceeding 0.01 , except for the years 2002 and 2007 when they reached 0.098 and 0.022 , respectively. Consistent with the findings of prior studies, the responsiveness of stock prices to changes in EPS is much higher than the one observed for BVPS. The mean value of coefficient $\beta_{1}$ equals 12.731 , with a median of 11.840. The lowest value of coefficient $\beta_{1}$ occurred in 1999 (7.135), while the highest one (20.223) in 2006. The dispersion of regression coefficients for EPS also turns out to be higher than in the case of BVPS. In comparison to Model 1 the predictive power of Model 2 turns out to be much more unstable, as in 2002 the changes of EPS were able to explain merely $23 \%$ of the variance in banks' stock prices, while in 2006 the coefficient of determination reached $97.5 \%$.

Similarly to the results obtained for the separate financial statements all yearly regression coefficients estimated for both models on the basis of consolidated data are statistically significant. Only in the case of the estimate of parameter $\beta_{1}$ for the year 2002, the $p$-value exceeds conventionally acceptable levels. The estimates of pameters $\alpha_{1}$ exhibit a slightly higher dispersion than in the case of separate data and vary from 1.169 in 2008 to 3.132 in 2006, with a mean of 1.785 and a median of 1.690. The changes in the consolidated BVPS are able to explain from $80.9 \%$ to $99.2 \%$ of the variance in banks' stock prices.

In order to investigate the impact of the market cycle on the observed fluctuations in the coefficients of regression and determination for Models 1 and 2 their estimates have been compared with the yearly rates of return on the WIG Index. Figures 1 and 2 illustrate the results of this analysis for the separate financial statements.

Figure 1 suggests that the sensitivity of banks' stock prices to changes in BVPS was at least partially driven by the course of the market cycle in the analyzed period. This association seems particularly pronounced after the year 2005 (i.e. since the adoption of the International Financial Reporting Standards in Poland). In contrast, in the period 1997-2004 the fluctuations in the WIG Index do not seem to have caused evident changes in the 


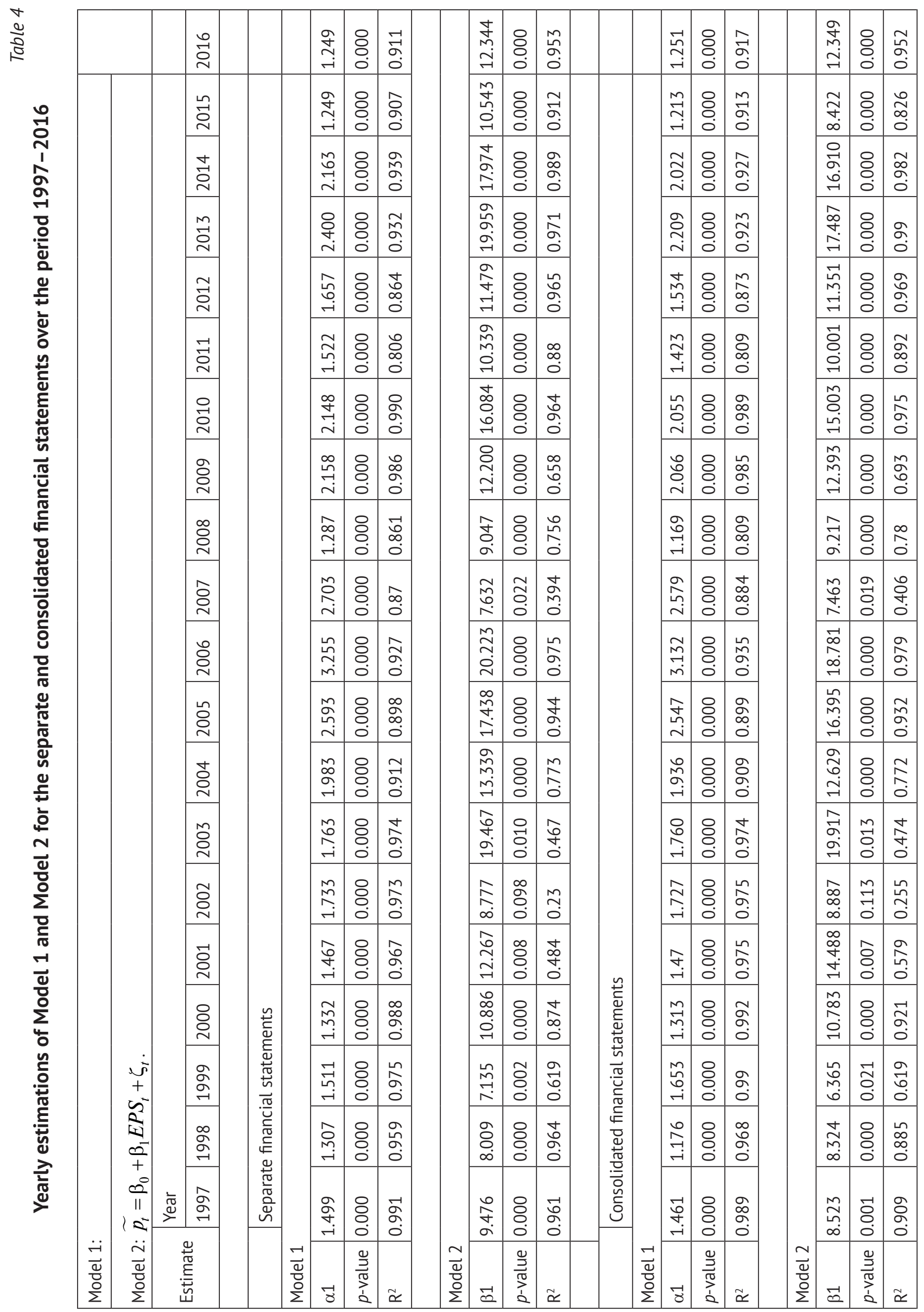



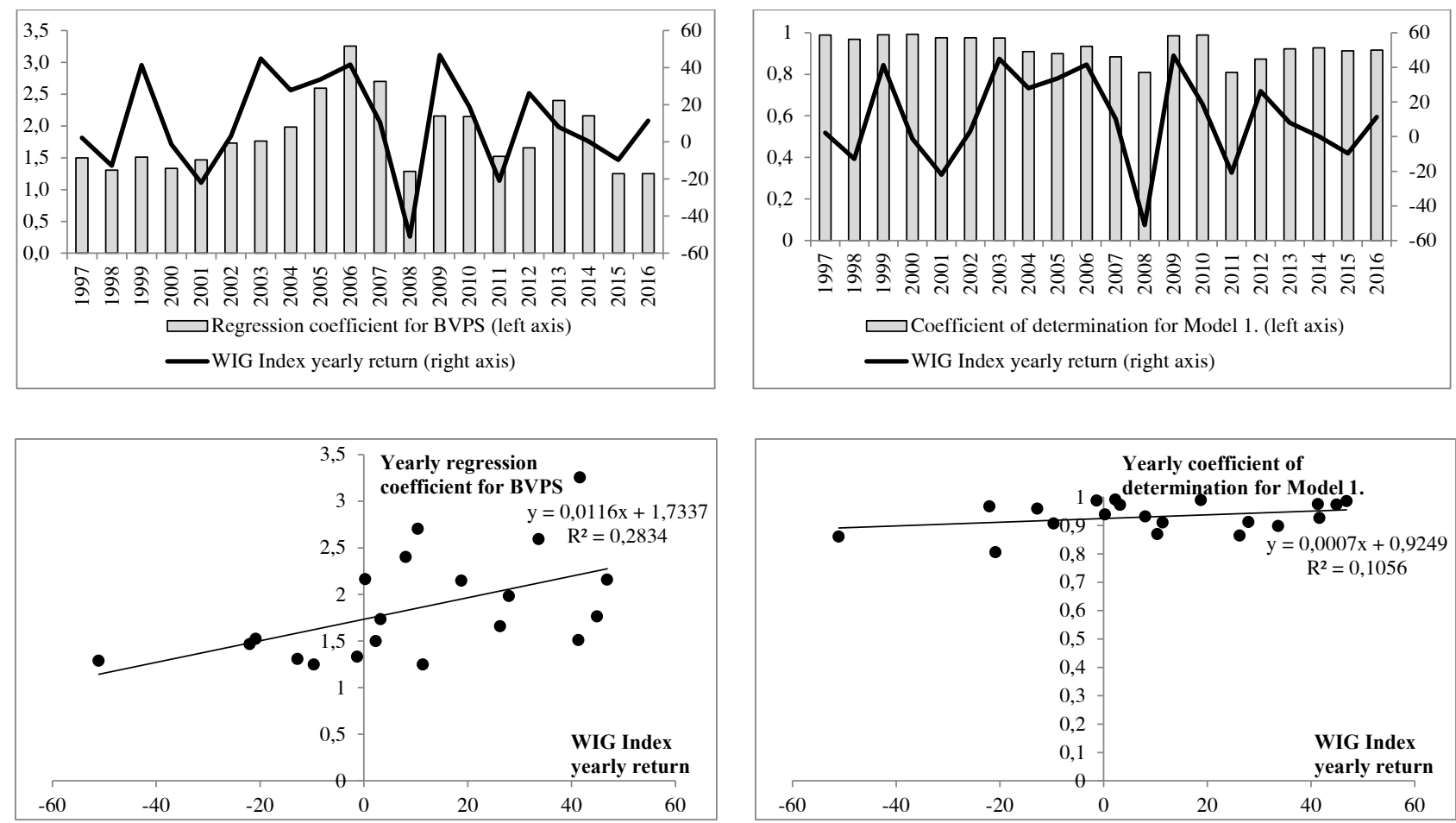

\section{Fig. 1. WIG Index yearly returns vs. the yearly coefficients of regression and determination for Model 1 for the separate financial statements over the period 1997-2016}

examined regression coefficient. A scatterplot of yearly regression coefficients between banks' stock prices and BVPS versus the WIG Index yearly returns confirms a positive association between the examined variables.

The values of the Pearson correlation and Spearman's $\rho$ between the yearly regression coefficients of Model 1 and the WIG Index annual growth rates equal $0.532(p-$ value $=0.016)$ and $0.577(p$-value $=0.008)$, respectively, which indicates a moderate positive association. Additionally, the results of the regression analysis demonstrate that on average a 1 percent point increase in the WIG Index yearly return contributes to an increase in the regression coefficient between banks' stock prices and BVPS by 0.0116 . The changes of the WIG Index yearly returns are able to explain slightly more than $28 \%$ of the variance in the sensitivity of stock prices to changes in BVPS.

Over the period 1997-2003, the fluctuations of the WIG Index growth rate do not seem to have exerted any substantial impact on the ability of BVPS to explain the variance in banks' stock prices. Since 2004, the volatility of yearly coefficients of determination for Model 1 has somewhat increased, however, their association with the fluctuations of the WIG Index yearly returns is rather weak. The above impression is confirmed by the results of the correlation and regression analyses. The estimated values of both parametric and non-parametric correlation coefficients turn out to be positive, however low (0.323 and 0.217 , respectively) and statistically insignificant.

The above results suggest that the course of the market cycle seems to be partially driving the fluctuations of the value relevance of book values of equity in the Polish banking industry over the examined period, thus providing some support the first hypothesis of the present study. The impact of shifting investors' sentiments is most explicit and statistically significant in the case of the sensitivity of banks' stock prices to changes in BVPS. There is also some weak evidence that the observed fluctuations in the ability of BVPS to explain the variance in banks' stock prices might be partially attributable to the market cycle.

In the next step of the research analogous analyses for EPS. The data that are shown in Figure 2 also suggest some impact of the market cycle on the value relevance of banks' earnings. The pattern, however, seems more ambiguous. Although the periods of the bear market usually decrease the sensitivity of banks' market values to reported earnings, while bullish sentiments generally increase them, there are also pronounced discrepancies in both timing and magnitude of the regression coefficients' response to the changes in the WIG Index yearly returns. In comparison to the regressions between banks' stock prices and BVPS, the ones for EPS seem much more volatile and weaker associated with the course of the market cycle. The value of the Pearson correlation 

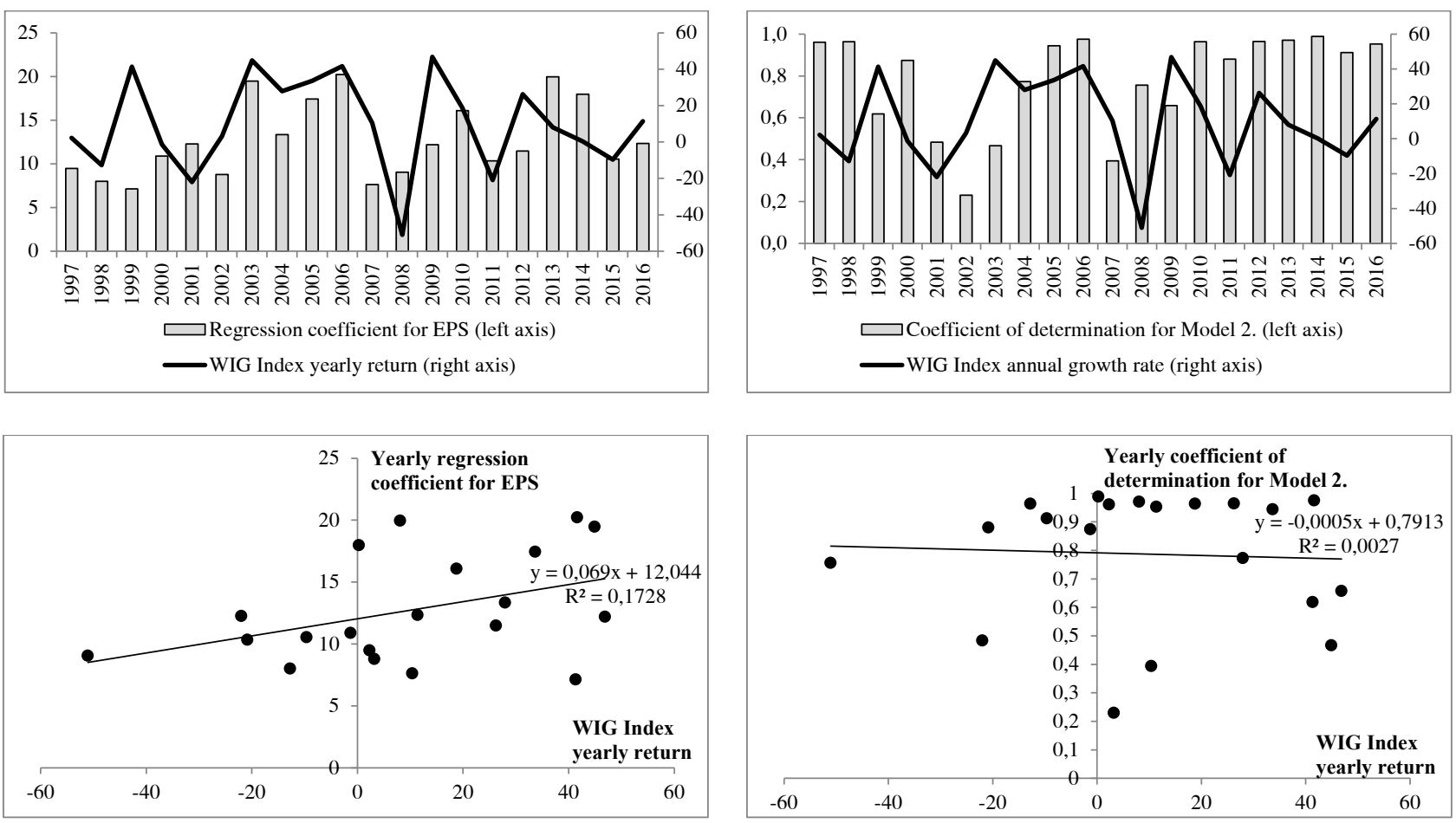

\section{Fig. 2. WIG Index yearly returns vs. the yearly coefficients of regression and determination for Model 2 for the separate financial statements over the period 1997-2016}

coefficient between the yearly regression parameters in Model 2 and the WIG Index yearly returns is 0.416 $(p$-value $=0.068)$ while the Spearman's rank coefficient equals $0.394(p$-value $=0.086)$. On average, a 1 percent point increase in the WIG Index yearly return results in an increase of the regression coefficient for EPS by 0.0690). The changes in the WIG Index yearly returns are also able to explain only $17.28 \%$ of the variance in sensitivity of banks' stock prices to EPS.

The volatility of coefficients of determination for Model 2 in the analyzed period also does not reveal any clear relationship with the course of the market cycle. The estimated parametric and non-parametric correlation coefficients are insignificantly different from zero. Even though the ability of EPS to explain the variance in banks' stock prices varies significantly across the examined period, the empirical evidence does not indicate that this volatility might be attributable to the changing sentiments of the equity investors.

The empirical evidence on the impact of market cycle on the value relevance of banks' separate earnings seems to be clearly weaker than the one observed for book values of equity and also most pronounced in the case of the sensitivity of banks' stock prices to changes in EPS, which provides some weak support for the first hypothesis of the study. In contrast, strong fluctuations in the ability of EPS to explain the variance in banks' stock prices appear to be driven primarily by factors other than market cycle. The above results suggest, therefore, rejection of the second hypothesis of the present study.

Similarly to the results obtained for the separate financial statements, comparisons of the annual changes in the WIG Index yearly returns with the fluctuations in the coefficients of regression and determination of Models 1 and 2 estimated on the basis of consolidated data (Figures 3 and 4 ) suggest that the variations in the value relevance of these accounting variables might be partially driven by the course of the market cycle.

The results of the analyses of correlation and regression indicate a slightly stronger positive association between the market cycle and the sensitivity of banks' stock prices to changes in consolidated BVPS compared to separate data. The Pearson coefficient equals 0.591 ( $p$-value $=0.006)$, while the Spearman's $\rho$ is even higher, reaching $0.669(p$-value $=0.001)$. An increase in the WIG Index yearly return of 1 percent point results on average in an increase of the value of regression coefficient between banks' stock prices and consolidated BVPS by 0.0122 . Overall, the fluctuations of the WIG Index yearly returns are able to explain almost $35 \%$ of the variance in the examined regression coefficients, i.e. over 6 percent points more than in the case of separate financial statements.

Similarly to the results obtained on the basis of the separate financial statements, the responsiveness of the yearly coefficients of determination for Model 1 . 

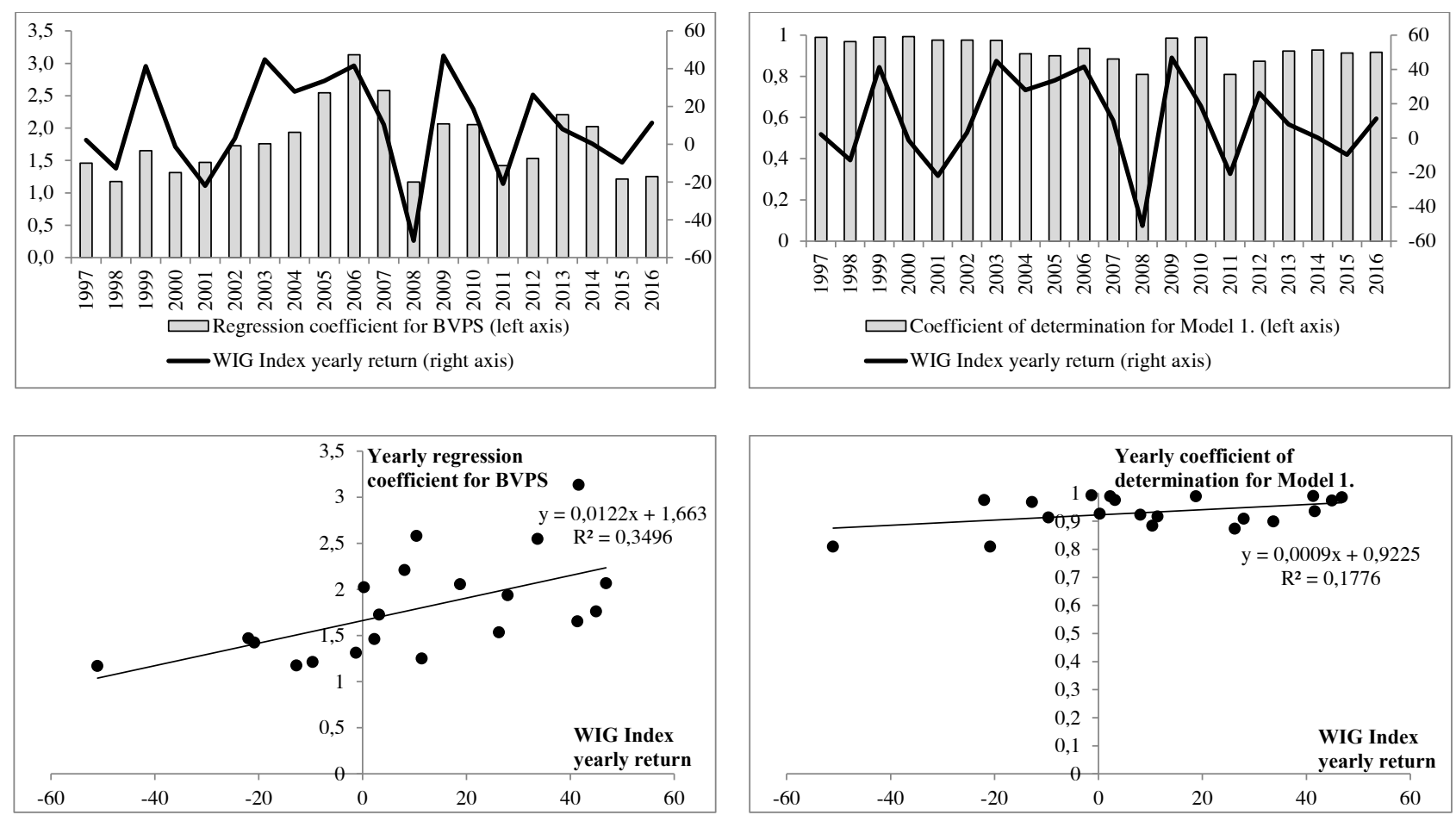

\section{Fig. 3. WIG Index yearly returns vs. the yearly coefficients of regression and determination for Model 1 for the consolidated financial statements over the period 1997-2016}

to the fluctuations in the WIG Index yearly returns in the period 1997-2003 seems rather limited. Since 2005, however, the changes in the course of the market cycle appear to have exerted a much stronger impact on the value relevance of consolidated book values of banks' equity. Over the entire analyzed period, the Pearson correlation coefficient between these variables equals 0.421 ( $p$-value of 0.064 ), whereas Spearman's $\rho$ is much lower (0.197) and statistically insignificant.

Just as in the case of the separate data, the value relevance of consolidated book values of equity in the Polish banking sector over the analyzed period appears to be partially driven by the course of the market cycle. The evidence for consolidated data is somewhat stronger than the one obtained for the separate financial statements, but still, it is more evident in reference to the sensitivity of banks' stock prices to changes in BVPS than in the ability of BVPS to explain the variance in those prices. The above findings provide therefore some further support for the first hypothesis of the study.

The value relevance of consolidated EPS also reveals some dependence on the course of the market cycle in the analyzed period. The scatterplot of the yearly regression coefficients between bank stock prices and EPS versus the changes in the WIG Index yearly returns suggests, however, a rather weak association.

The estimates of the correlation coefficients indicate that the link between the changes the WIG Index yearly returns and the sensitivity of banks' stock prices to consolidated EPS is even weaker than in the case of the separate data. The Pearson coefficient is 0.386 , whereas the Spearman's correlation equals 0.379 . Both estimates, however, turn out to be statistically significant only at the $10 \%$ level (with $p$-values of 0.092 and 0.099 , respectively).

Just as in the case of separate financial statements, the volatility of the yearly coefficients of determination for Model 2 estimated on the basis of consolidated data does not reveal a clear relationship with the magnitude and timing of the fluctuations in the WIG Index yearly returns. Both the Pearson correlation and Spearman's $\rho$ between the yearly coefficients of determination for Model 2 and the changes in the WIG Index yearly returns are insignificantly different from zero. It seems, therefore, that the volatility of the value relevance of both consolidated and separate net earnings is driven mostly by other factors than the course of the market cycle.

Unlike for the book values of equity, the impact of the market cycle on the value relevance of consolidated net earnings seems weaker than that observed for separate data. Contrary to expectations, it appears that earnings exhibit a lower sensitivity of their value relevance to changes in equity investors' sentiments than book values, which in turn provides some further arguments for rejection of the second hypothesis of the study.

The final stage of the investigation aims at empirical evaluation of the impact of economic downturns on the 

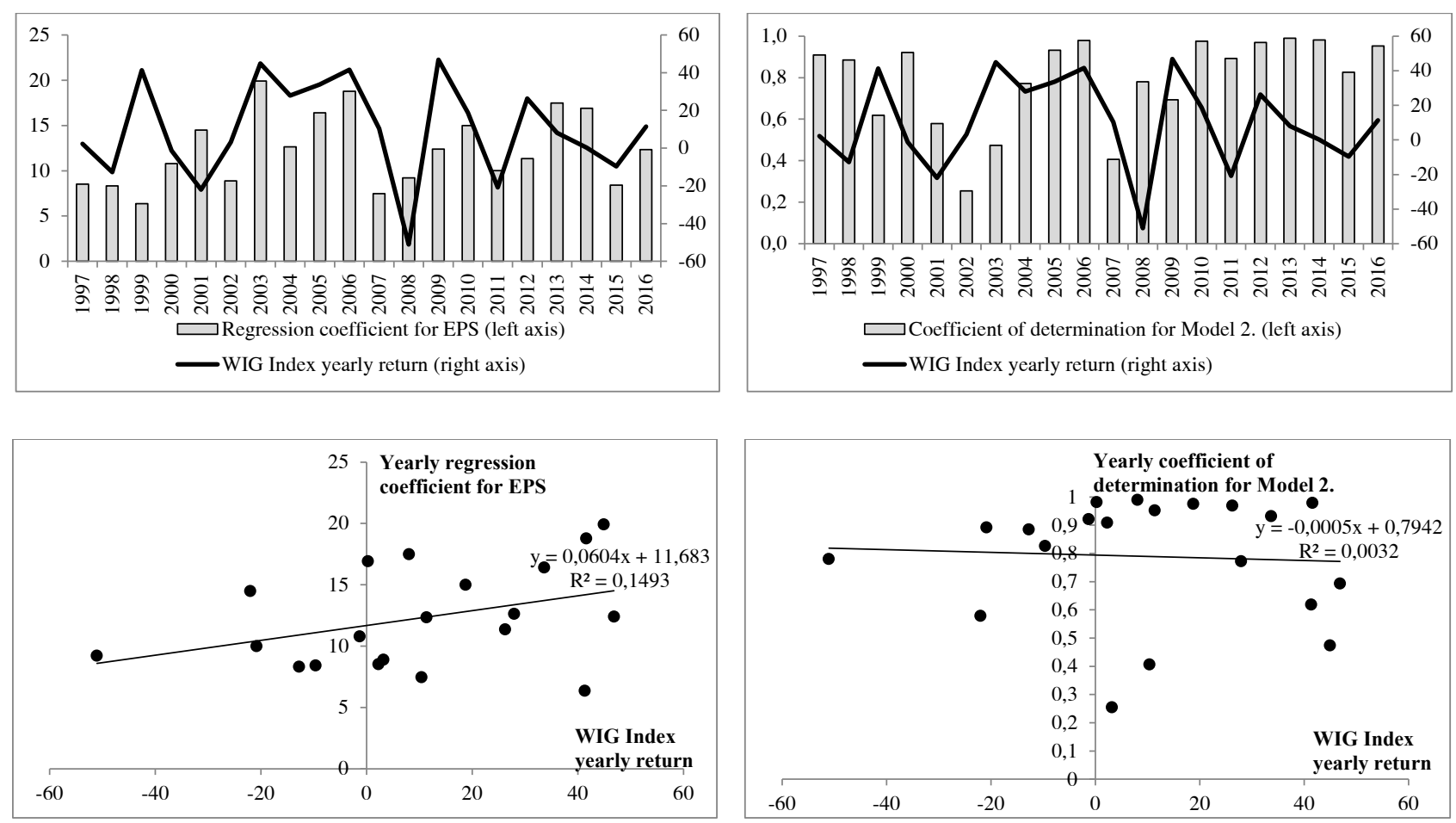

\section{Fig. 4. WIG Index yearly returns vs. the yearly coefficients of regression and determination for Model 2 for the consolidated financial statements the over the period 1997-2016}

value relevance of both book values of equity and net earnings. The results of estimations of Model 3 for both separate and consolidated data are shown in Table 5.

The model is statistically significant at conventional levels for both types of financial statements. Additionally, relatively low values of variance inflation factors (VIF) do not reveal any serious problems with collinearity of the explanatory variables. The changes in the regressors are able to explain over $87 \%$ of the variance in banks' market values. The predictive power for consolidated data is slightly higher compared to the estimation based on the separate financial statements. The estimates of parameters $\gamma_{1}$ and $\gamma_{2}$ are positive and statistically significant, indicating that increases in BVPS and EPS are positively associated with stock prices in the periods of bullish sentiments. Additionally, the sensitivity of banks' stock prices to changes in both consolidated BVPS and EPS in those periods seems to be somewhat lower than in the case of separate statements.

Consistent with expectations, the estimates of parameters $\gamma_{3}$ and $\gamma_{4}$ are negative, indicating a lower responsiveness of banks' stock prices to the changes in both BVPS and EPS in the bearish periods of the market cycle. Interestingly, the decrease in the value relevance of book values is more pronounced in the case of consolidated data while for net earnings it is clearly higher in the case of separate statements. The parameter $\gamma_{3}$ turns out to be statistically significant at $p<0.05$ for both types of analyzed financial statements. The $p$-values for the estimates of $\gamma_{4}$, however, are markedly higher, and in fact, it might be considered significant (at $p=0.10$ ) only in the case of separate data. A statistically significant break in regression parameters for both separate and consolidated statements is further confirmed by the results of the Chow test. The above findings indicate that the periods of economic downturns and prevailing bearish sentiments generally decrease the value relevance of both examined accounting variables, which supports the third hypothesis of the present study. The empirical evidence of this impact in the analyzed sample of banks, however, seems much stronger in the case of book values of equity.

\section{DISCUSSION AND CONCLUSIONS}

The present study attempts to contribute to the existing pool of knowledge in the following ways. First, by providing some insights on the impact of changing market sentiments on the value relevance of fundamental accounting variables and second, by extending the literature on the value relevance of banks' financial reporting in the emerging economies.

The results of the research indicate that the course of the market cycle is partially driving the fluctuations of the value relevance of book values of equity and net earnings in the Polish banking industry. The empirical evidence obtained for both separate and consolidated 
Estimations of Model 3 for the separate and consolidated financial statements (pooled sample)

\begin{tabular}{|c|c|c|c|c|c|c|c|c|c|c|c|c|}
\hline \multirow[b]{3}{*}{ Parameter/statistic } & \multicolumn{6}{|c|}{ Separate financial statements } & \multicolumn{6}{|c|}{ Consolidated financial statements } \\
\hline & \multirow{2}{*}{$\begin{array}{c}\text { Esti- } \\
\text { mate/ } \\
\text { value }\end{array}$} & \multirow{2}{*}{$\begin{array}{c}\text { Std. er- } \\
\text { ror }\end{array}$} & \multirow{2}{*}{$\begin{array}{l}\text { t-statis- } \\
\text { tic }\end{array}$} & \multirow[b]{2}{*}{ Sig. } & \multicolumn{2}{|c|}{ Collinearity statistics } & \multirow{2}{*}{$\begin{array}{l}\text { Esti- } \\
\text { mate/ } \\
\text { value }\end{array}$} & \multirow{2}{*}{$\begin{array}{c}\text { Std. Er- } \\
\text { ror }\end{array}$} & \multirow{2}{*}{$\begin{array}{c}\text { t-statis- } \\
\text { tic }\end{array}$} & \multirow[b]{2}{*}{ Sig. } & \multicolumn{2}{|c|}{ Collinearity statistics } \\
\hline & & & & & $\begin{array}{l}\text { Toler- } \\
\text { ance }\end{array}$ & VIF & & & & & $\begin{array}{l}\text { Toler- } \\
\text { ance }\end{array}$ & VIF \\
\hline$\gamma_{0}$ & -4.497 & 5.394 & -0.834 & 0.405 & & & -2.022 & 5.508 & -0.367 & 0.714 & & \\
\hline$\gamma_{D 0}$ & 6.048 & 10.018 & 0.604 & 0.547 & 0.549 & 1.820 & 6.651 & 10.571 & 0.629 & 0.530 & 0.549 & 1.820 \\
\hline$\gamma_{1}$ & 1.600 & 0.097 & 16.494 & 0.000 & 0.251 & 3.978 & 1.532 & 0.097 & 15.800 & 0.000 & 0.244 & 4.100 \\
\hline$\gamma_{2}$ & 4.591 & 0.653 & 7.025 & 0.000 & 0.269 & 3.719 & 4.513 & 0.640 & 7.051 & 0.000 & 0.263 & 3.807 \\
\hline$\gamma_{3}$ & -0.473 & 0.220 & -2.152 & 0.032 & 0.125 & 7.996 & -0.537 & 0.209 & -2.567 & 0.011 & 0.138 & 7.247 \\
\hline$\gamma_{4}$ & -2.776 & 1.684 & -1.649 & 0.100 & 0.153 & 6.545 & -2.006 & 1.602 & -1.253 & 0.212 & 0.176 & 5.673 \\
\hline F-statistic & 350.512 & & & 0.000 & & & 342.026 & & & 0.000 & & \\
\hline $\mathrm{R}^{2}$ & 0.873 & & & & & & 0.878 & & & & & \\
\hline Adj. $R^{2}$ & 0.871 & & & & & & 0.876 & & & & & \\
\hline Chow test statistic & 25.851 & & & 0.000 & & & 23.485 & & & 0.000 & & \\
\hline N & 260 & & & & & & 243 & & & & & \\
\hline$N_{1 \text { (bullish) }}$ & 181 & & & & & & 172 & & & & & \\
\hline $\mathrm{N}_{2(\text { bearish) }}$ & 79 & & & & & & 71 & & & & & \\
\hline
\end{tabular}

financial statements suggest that the timing and magnitude of changes in the rate of return on a broad market index (WIG) appear to be generally reflected by the observed fluctuations in the sensitivity of banks' stock prices to changes in BVPS and EPS. In the periods of a bull market, the value relevance of both book values and earnings tends to improve while the periods of bearish sentiments usually decrease it. In turn, the impact of the market cycle on the ability of the examined accounting variables to explain the variance in banks' stock prices is much weaker and in fact detectable only in the case of book values of equity.

Interestingly, the influence of the changing investors' sentiments on the value relevance of book values of equity and earnings has clearly amplified after the year 2004. This observation suggests that an increased sensitivity of the value relevance of accounting data to the course of the market cycle might result from the changes in the regulatory environment, in particular, the adoption of the International Financial Reporting Standards that became mandatory for consolidated statements of listed companies since 2005. In the case of banks, other major changes in the examined period regard the implementation of the Basel II and Basel III regulations, and in particular their impact on estimation of minimum capital requirements and asset impairment under the internal ratings-based approaches.

The empirical evidence on the impact of the market cycle on the value relevance of banks' earnings appears to be markedly weaker than the one observed for book values of equity. For both separate and consolidated statements, this influence is most pronounced in the case of the responsiveness of banks' stock prices to changes in EPS, whereas the ability of earnings to explain the variance in the market value seems largely unaffected by the shifts of investors' sentiments. Therefore, even though the value relevance of earnings in the Polish banking sector seems quite unstable over the examined period, the empirical evidence suggests that its fluctuations are driven primarily by factors other than the course of the market cycle. In particular, it seems likely that this volatility might be largely attributable to the aforementioned intensity of the regulatory activities.

The findings of the study also suggest that the impact of the market cycle on the value relevance of accounting variables might, in fact, differ for separate and consolidated statements. In the case of book values of 
equity, the shifts in market sentiments exert a stronger influence on the value relevance of consolidated data. In contrast, the value relevance of banks' earnings seems to be more sensitive to the course of the market cycle when the separate statements are analyzed.

Consistent with the results of the majority of prior investigations in the relevant literature, the findings of the study also indicate that the periods of economic downturns and prevailing bearish sentiments in the capital markets generally decrease the value relevance of both book values of equity and earnings in the banking industry. Additionally, the decrease in the value relevance of book values seems to be more pronounced in the case of consolidated data while for the net earnings it appears to be stronger for the separate statements.

For both separate and consolidated data, the value relevance of book values of equity seems to be more robust to adverse sentiments than the value relevance of earnings. This observation might result from the fact that book value of equity is typically perceived by the investors as a proxy for bank liquidation value, but in the times of expansion and bullish sentiments, it might also determine their perception of banks' ability to increase the scale of their risky operations. The value relevance of earnings usually drops considerably in adverse economic conditions, which suggests that equity investors become less convinced of the usefulness of current earnings as predictors of the future banks' performance, especially when the reported earnings numbers are likely to be subject to management discretion and income smoothing practices, and when the regulatory environment becomes increasingly volatile.

The results of the research indicate a need for further investigation of the impact of market cycles on the value relevance of accounting data, not only in the context of the banking sector. In particular, the future research might try to explore the impact of the changes in the regulatory environment on the sensitivity of the value relevance of accounting-based variables to the shifting sentiments of equity investors.

\section{REFERENCES}

1. Koller T., Goedhart M., Wessels D. Valuation. Measuring and managing the value of companies. 5th ed. New Jersey, NJ: John Wiley \& Sons; 2010.

2. Ball R., Brown P. An empirical evaluation of accounting income numbers. Journal of Accounting Research. 1968;6(2):159-178.

3. Kohlbeck M., Warfield T. Unrecorded intangible assets: Abnormal earnings and valuation. Accounting Horizons. 2007;21(1):23-41.

4. Subramanyam K.R., Venkatachalam M. The role of book value in equity valuation: Does the stock variable merely proxy for relevant past flows? University of Stanford Research Paper No. 1491R; 1998. Retrieved from https://www.gsb.stanford.edu/gsb-cmis/gsb-cmis-download-auth/316866.

5. Obinata T. Concept and relevance of income. The University of Tokyo, Graduate School of Economics, CIRJE Discussion Paper 2002-CF-171; 2002. Retrieved from https://ssrn.com/abstract=339060.

6. Nichols D.C., Wahlen J. How do earnings numbers relate to stock returns? A review of classic accounting research with updated evidence. Accounting Horizons. 2004;18(4):263-286.

7. Escaffre L., Sefsaf R. Comparing the value relevance of earnings and book value in IFRS and GAAP standards. Bankers, Markets and Investors. 2011;114:4-18.

8. Anandarajan A., Francis B., Hasan I., John K. Value relevance of banks: global evidence. Review of Quantitative Finance \& Accounting. 2001;36(1):33-55.

9. Bolibok P. The relative value relevance of earnings, book values and cash flows in the Polish banking sector. Journal of Financial Management and Accounting. 2015;3(4):19-31.

10. Amor-Tapia B., Bona-Sánchez C., Pérez-Alemán J., Tascón-Fendández M. Earnings conservatism and litigation exposure in the banking industry. Revista Española de Financiación y Contabilidad. 2011;40(152):556-585.

11. Koziński W. The international banking crisis and domestic financial intermediation: the experience of Poland. BIS Papers. 2010;54:343-346.

12. Kane G., Leece R., Richardson F., Velury U. The impact of the recession on the value-relevance of accounting information. Australian Accounting Review. 2015;73(25):185-191.

13. Barth M. Fair value accounting: Evidence from investment securities and the market valuation of banks. The Accounting Review. 1994;69(1):1-25.

14. Ahmed A., Kilic E., Lobo G. Does recognition versus disclosure matter? Evidence from value-relevance of banks' recognized and disclosed derivative instruments. The Accounting Review. 2006;81(3):567-588.

15. Bernard V., Merton R., Palepu K. Mark-to-market accounting for banks and thrifts: Lessons from the Danish experience. Journal of Accounting Research. 1995;33(1):1-32. 
16. Eccher E., Ramesh K., Thiagarajan S. Fair value disclosures by bank holding companies. Journal of Accounting and Economics. 1996;22:79-117.

17. Nelson K. Fair value accounting for commercial banks: An empirical analysis of SFAS No. 107. The Accounting Review. 1996;71(2):161-182.

18. Barth M., Clinch G. Revalued financial, tangible, and intangible assets: Associations with share prices and nonmarket-based value estimates. Journal of Accounting Research. 1998;36 (Suppl.):199-233.

19. Beaver W., Eger C., Ryan S., Wolfson M. Financial reporting, supplemental disclosures, and bank share prices. Journal of Accounting Research. 1989;27(2):157-178.

20. Beaver W., Venkatachalam M. Differential pricing of components of bank loan fair values. Journal of Accounting, Auditing, and Finance. 2003;18:41-67.

21. Venkatachalam M. Value-relevance of banks' derivatives disclosures. Journal of Accounting and Economics. 1996;22(1-3):327-355.

22. Park M., Park T., Ro B. Fair value disclosures for investment securities and bank equity: Evidence from SFAS No. 115. Journal of Accounting, Auditing, and Finance, 1999;14(3):347-370.

23. Philips G.E., Mayne L. Income measures and bank stock values. Journal of Accounting Research. 1970;8:178-188.

24. Wahlen J. The nature of information in commercial bank loan loss disclosures. The Accounting Review. 1994;69(3):455-478.

25. Beaver W., Engel E. Discretionary behavior with respect to allowances for loan losses and the behavior of security prices. Journal of Accounting and Economics. 1996;22:177-206.

26. Ahmed A., Takeda C. Stock market valuation of gains and losses on commercial banks' investment securities. An empirical analysis. Journal of Accounting and Economics. 1995;20:207-225.

27. Lim C., Walker M., Lee E. Are the loan loss and fair value components of bank income rationally priced? Paper presented at Marie Curie ITN Final Conference on Financial Risk Management \& Risk Reporting, University of Konstanz, Germany; 2013, April.

28. Bolibok P. Value relevance of impairment provisions in the Polish banking sector. Research Papers of Wroclaw University of Economics. 2015;397:58-67.

29. Ryan S., Tucker J., Zarowin P. Classification and market pricing of the cash flows and accruals on trading positions. The Accounting Review. 2006;81(2):443-472.

30. Hodder L., Hopkins P., Wahlen J. Risk-relevance of fair-value income measures for commercial banks. The Accounting Review. 2006;81(2):337-375.

31. Cheng F.-F., Ariff M. Abnormal returns of bank stocks and their factor-analyzed determinants. Journal of Accounting, Business \& Management. 2007;14:1-16.

32. Cheng F.-F., Annuar N. The effect of financial risks on the earnings response in Australian bank stocks. Journal of Money, Investment, and Banking. 2008;6:17-26.

33. Soh W.N., Cheng F.-F., Annuar N. The effect of financial risk on the earnings response in Thailand banks' stock. International Journal of Finance and Economics. 2009;31:55-65.

34. Abuzayed B., Molyneux P., Al-Fayoumi N. Market value, book value, and earnings: is bank efficiency a missing link? Managerial Finance. 2009;35(2):156-179.

35. Siam W., Rashid K. The impact of income statement components decomposition on share market value of the Jordanian commercial banks. International Journal of Business, Accounting, and Finance. 2010;4(2):84-101.

36. Al-Horani A. Testing the relationship between abnormal returns and non-interest earnings: The case of Jordanian commercial banks. International Research Journal of Finance and Economics. 2010;55:108-117.

37. Dimitropoulos P., Asteriou D., Koumanakos E. The relevance of earnings and cash flows in a heavily regulated industry: Evidence from the Greek banking sector. Advances in Accounting. 2010;26:290-303.

38. Tjhoa E., Hermawan A. Informativeness of earnings and cash flows: Evidence in Indonesia, Malaysia, and Thailand banking industry; 2014. Retrieved from URL: http://www.af.polyu.edu.hk/files/jiar2014/cc078\%20 paper\%20elisa\%20and\%20ancella_final.pdf.

39. Ohlson J. Earnings, book values, and dividends in equity valuation. Contemporary Accounting Research. 1995;11(2):661-687.

40. Bolibok P. Application of the Ohlson model for testing the value relevance of accounting data in Polish banking sector. Finanse, Rynki Finansowe, Ubezpieczenia. 2014;65:463-471.

41. Gao Z., Li W., O’Hanlon J. The informativeness of US banks' statements of cash flows; 2016. URL: https://dx.doi. org/10.2139/ssrn.2568762. 
42. Agostino M., Drago D., Silipo D. The value relevance of IFRS in the European banking industry. Review of Quantitative Finance and Accounting. 2011;36(23):437-457.

43. Bolibok P. The impact of IFRS on the value relevance of accounting data of banks listed on the Warsaw Stock Exchange. Copernican Journal of Finance and Accounting. 2014;3(1):33-43.

44. Bolibok P. Does standardization of accounting improve the value relevance of financial reporting in banking sector? Journal of Financial Management and Accounting. 2015;3(2):65-76.

45. Dobija D., Klimczak K. Development of accounting in Poland: Market efficiency and the value relevance of reported earnings. The International Journal of Accounting. 2010;45:356-374.

46. Klimczak K. Market reaction to mandatory IFRS adoption: Evidence from Poland. Accounting and Management Information Systems. 2011;10(2):228-248.

47. Hayn C. The information content of losses. Journal of Accounting and Economics. 1995;20(2):125-153.

48. Elliott J., Hanna J.D. Repeated accounting write-offs and the information content of earnings. Journal of Accounting Research. 1996;34:135-155.

49. Basu S. The conservatism principle and the asymmetric timeliness of earnings. Journal of Accounting and Economics. 1997;24(1):3-37.

50. Davis-Friday P., Gordon E. Relative valuation roles of equity book value, net income, and cash flows during a macroeconomic shock: The case of Mexico and the 1994 currency crisis. Journal of International Accounting Research. 2005;4(1):1-21.

51. Graham R., King R., Bailes J. The value relevance of accounting information during a financial crisis: Thailand and the 1997 decline in the value of the Baht. Journal of International Financial Management and Accounting. 2000;11(2):84-107.

52. Ho L.-C., Liu C.-S., Sohn P. The value relevance of accounting information around the 1997 Asian financial crisis - the case of South Korea. Asia-Pacific Journal of Accounting \& Economics. 2001;8(2):83-107.

53. Eng L.L., Nabar S., Chng C.K. The predictive value of earnings, cash flows and accruals in the period surrounding the Asian financial crisis: Evidence from Hong Kong, Malaysia, Singapore, and Thailand. Journal of International Financial Management and Accounting. 2005;16(3):165-193.

54. Johnson M. Business cycles and the relationship between security returns and earnings. Review of Accounting Studies. 1999;4(2):93-117.

55. Jenkins D., Kane G., Velury U. Earnings conservatism and value relevance across the business cycle. Journal of Business Finance and Accounting. 2009;36:1041-1058.

56. Bepari M. Relative and incremental value relevance of book value and earnings during the global financial crisis. International Journal of Commerce and Management. 2015;25(4):531-556.

57. Persakis A., Iatridis G. Earnings quality under financial crisis: A global empirical investigation. Journal of Multinational Financial Management. 2015;30:1-35.

58. Cohen L., Cornett M., Marcus A., Tehranian H. Bank earnings management and tail risk during the financial crisis. Journal of Money, Credit and Banking. 2014;46(1):171-197.

59. Ma M., Song V. Discretionary loan loss provisions and systemic risk in the banking industry. Accounting Perspectives. 2016;15(2):89-130.

60. Morris R.D., Kang H., Jie J. The determinants and value relevance of banks' discretionary loan loss provisions during the financial crisis. Journal of Contemporary Accounting \& Economics. 2016;12:176-190.

61. Bolibok P. The impact of the global financial crisis on the value relevance of leverage in the Polish banking sector. Finanse, Rynki Finansowe, Ubezpieczenia, 2016;4 (82/2):679-688.

62. Dougherty C. Introduction to econometrics. 4th ed. New York, NY: Oxford University Press; 2011.

\section{ABOUT THE AUTHOR}

Piotr M. Bolibok - Ph.D., Department of Banking and Finance, The John Paul II Catholic University of Lublin, Al. Racławickie 14, 20-950 Lublin, Poland

piotr.bolibok@kul.pl

\section{ИНФОРМАЦИЯ ОБ АВТОРЕ}

Петр Марек Болибок - кандидат экономических наук, Кафедра банковского дела и финансов, Люблинский католический университет им. Иоанна Павла II, Люблин, Польша piotr.bolibok@kul.pl 